\title{
MEMBANGUN KARAKTER SISWA MELALUI PEMBELAJARAN MATEMATIKA YANG BERINTEGRASI KEISLAMAN
}

\author{
Indun Ariningsih ${ }^{1}$ dan Rizki Amalia ${ }^{2}$ \\ Program Studi Pendidikan Matematika, Tarbiyah, Universitas Islam Sultan Syarif \\ Kasim Riau, Pekanbaru ${ }^{1}$ \\ Program Studi Pendidikan Guru Pendidikan Anak Usia Dini, Fakultas IImu \\ Pendidikan, Universitas Pahlawan Tuanku Tambusai, Bangkinang ${ }^{2}$
}

Email : indunariningsih@gmail.com

\begin{abstract}
Abstrak
Tujuan pendidikan Indonesia tercantum dalam undang-undang no. 20 Tahun 2003. Menyebutkan bahwa tujuan pendidikan nasional adalah mengembangkan potensi peserta didik agar memiliki kecerdasarn intelektual dan kecerdasan spiritual seperti beriman, bertakwa, berakhlak mulia, sehingga dapat menjadi warga negara yang demokratis dan bertanggung jawab. Untuk dapat mencapai tujuan tersebut, diperlukan peran seorang guru dalam membagun karakter siswa agar memilki karakter atau akhlak yang mulia. Namun, dalam hal ini bukan saja tugas seorang guru bimbingan dan konseling tetapi tugas semua guru yang ada di sekolah tersebut, termasuk guru mata pelajaran. Salah satu saran yang diperlukan untuk mencapai tujuan tersebut adalah bahan ajar. Peran seorang pendidik harus memperhatikan kelayakn bahan ajar yang berintegrasi keislaman sehingga nantinya peseta didik tidak hanya memiliki kecerdasan intelektual tetapi juga memiliki kecerdasan spiritual. Membangun karakter siswa juga dapat dilakukan oleh guru mata pelajaran matematika dengan cara melakukan pembelajaran matematika dengan mengaitkanya dengan nilai-nilai keislaman.
\end{abstract}

Kata kunci: Membangun Karakter, Pembelajaran Matematika, berintegrasi nilai-nilai Keislaman

\section{PENDAHULUAN}

Lembaga Pendidikan di Indonesia bukan saja harus mencetak lulusan yang memeliki kecerdasan intelektual saja, tetapi harus mampu menciptakan peserta didik yang memiliki kecerdasan religius. Dewasa ini lembaga pendidikan di Indonesia di hadapkan dengan tantangan yang jauh lebih kompleks, disamping harus mampu menciptakan peserta didik yang mengerti ilmu agama dan juga ilmu umum, lembaga pendidikan juga dituntut untuk dapat melahirkan generasi yang berkarakter serta memiliki moral yang baik. Jika kita melihat fenomena yang terjadi saat ini, banyak kasus seorang siswa menentang gurunya, dimana seorang siswa tidak memilki rasa hormat kepada gurunya bahkan dia berani menantang gurunya di depan umum. 
Kasus seperti ini sangat sering sekali terjadi, jika kita melihat beritaberita di televisi hampir sering sekali pemberitaan kasus murid melawan kepada gurunya,siswa yang menganiaya gurunya, siswa yang menendang gurunya, siswa yang membuli gurunya dan masih banyak lagi, fenomena-fenomena seperti ini sangat banyak terjadi di negara kita yaitu Indonesia. Kondisi pendidikan di Indonesia sangat bermasalah, lembaga pendidikan masih banyak yang belum mampu mendidik siswanya pendidikan karakter, pendidikan tata krama, pendidikan sopan santun. Hal ini ditandai dengan semakin maraknya kasus-kasus siswa yang menentang gurunya sendiri. Menjadi pertanyaan bagi kita semua apakah yang menyebabkan akhlak siswa semakin merosot, apakah ini dipengaruhi oleh kurikulum pendidikan yang kurang bagus atau karena apa? jika kita menyalahkan kurikulum tentu tidak logis karena kurikulum pastilah dibuat dengan mempertimbangkan berbagai hal sebelum diterapkan. Dengan merosotnya akhlak peserta didik saat ini, menjadi tugas berat bagi seorang guru untuk membagun karakter peserta didik agar peserta didik memiliki karakter yang lebih baik, mereka disekolah jangan hanya dituntut untuk memiliki kepintaran di mata pelajran saja tetapi juga harus memiliki sikap sopan santun, bisa menghormati orang yang lebih tua dan menghargai sesamanya. Dalam pandangan penulis, hal ini menunjukan masih belum berhasilnya proses pendidikan yang berjalan saat ini. sehingga diperlukan adanya upaya pendidikan terhadap siswa yang menitikberatkan pada pendidikan karakter.

Karakter adalah sifat, watak akhlak ataupun kepribadian seorang individu yang membendakannya dengan individu yang lain. Membangun Karakter siswa bukan merupakan tugas yang mudah bagi seorang guru. Oleh karena itu dalam membangun karakter siswa bukan saja menjadi peran guru BK Tetapi juga guru mata pelaran. Disini penulis membahas tentang membangun karakter siswa berdasarkan pembelajran matematika yang berintegrasi keislaman. Matematika adalah mata pelajaran yang pasti ada di semua jenjang pendidikan formal, oleh sebab itu pendidikan matematika juga dapat digunakan untuk membentuk karakter siswa, caranya adalah melalui pembelajaran dikelas dengan mengajarkan pelajaran matematika kepada murid yang secara konsisten menanamkan kebiasaan-kebiasaan dan menanamkan prilaku yang berkarakter, dan juga memasukan nilai-nilai keislaman dalam pembelajaran matematika di kelas.

\section{PEMBAHASAN}

\section{Pendidikan Karakter}

Karakter adalah sifat, watak akhlak ataupun kepribadian seorang individu yang membendakannya dengan individu yang lain. Departemen Pendidikan Nasional tahun 2010 dalam "jurnal tatag yuli eko siswono:2012" menuliskan bahwa karakter merupakan prilaku manusia yang berhubungan dengan tuhan yang Maha Esa, diri sendiri, sesama manusia, lingkungan dan kebangsaan yang terwujud dalam pikiran, sikap, perkataan dan perbuatan berdasarkan norma-norma agama, hukum, tata kama, budaya dan adat istiadat. Orang yang perilakuanya sesuai norma-noma disebut insan berkarakter mulia. sebenarnya karakter mencakup berbagai aspek seperi aspek psikologis, aspek moral dan aspek kognitif. Aspek Psikologis meliputi emosi, kepribadian, budi pekerti, sifat, tabiat tempramen, atau watak, sedangkan aspek moral yaitu berupa 
nilai-nilai yang disadari dan diyakini, ada juga aspek kognitif yang meliputi gaya berfikir, penalaran atau berbahasan. Oleh karena itu karakter bukan saja nilainilai tetapi juga kemampuan, keyakinan, moralitas, pengendalian emosi dan pengarahannya serta mewujudkan prilaku yang sebenarnya.(dalam Jurnal tatag yuli eko siswono: 2012).

Membangun karakter peserta didik bisa dilakukan dengan pendidikan yang mengarahkan dan menanamkan pendidikan karakter pada peserta didik. Elkin \& Sweet (2004) mendefinisikan pendidikan karakter sebagai pengajaran yang dirancang untuk mendidik dan membantu siswa mengembangkan nilai-nilai kewarganegaraan dasar dan karakter, etika pelayanan masyarakat sekitarnya, memperbaiki sekolah dan prestasi belajar siswa. Setiap pendidikan memiliki tujuan, sama halnya dengan pendidikan karakter. Pendidikan karakter memilki tujuan untuk mendidik siswa agar memiliki karakter yang mulia, sehingga siswa bisa lebih menghomati orang yang lebih tua dan menghargai sesamanya, sehingga tidak terjadi lagi prilaku-prilaku siswa yang menyimpang.

Kementrian Pendidikan dan Kebudayaan mengemukakan ada 4 prinsip mengembangkan karakter pendidikan yang harus di terapkan :

1. Berkelanjutan. Artinya pendidikan karakter adalah proses pembentukan karakter yang panjang dimulai dari awal sampai akhir proses pendidikan di sekolah. Mulai dari TK hingga SMA di tingkat pendidikan yang lebih tinggi, pendidikan karakter lebih berfokus pada pemberdayaan.

2. Melalui semua mata pelajaran, pengembangan diri, dan budaya pendidikan. Artinya proses pengembangan karakter dilakukan melalui setiap mata pelajaran di sekolah. Setiap program ekstrakurikuler, dan program co-krukuler berdasarkan standar isi kurikulum.

3. Nilai tidak tertangkap atau diajarkan, artinya nilai karakter bukan bahan ajar, tetapi ini adalah sesuatu yang bisa dipelajari oleh siswa. Guru tidak perlu mengubah materi ajar tetapi memberi kesempatan kepada siswa untuk menerapkan pendidikan karakter.

4. Proses belajar yang aktif dan menarik. Artinya proses pendidikan karakter menempatkan siswa sebagai subjek pembelajaran, dan suasana belajar sebaiknya hidup, aktif dan menarik.

Pendidikan karakter yang diberikan kepada peserta didik tidak memerlukan waktu yang terkhusus tetapi pendidikan karakter bisa diberikan kepada peserta didik di sela-sela guru mata pelajajaran mengajarkan materinya. Pendidikan matematika memiliki peran tidak hanya membekali siswa nilai edukasi yang bersifat mencerdaskan tetapi juga memberikan edukasi yang membantu membentuk karakter siswa. Membentuk karakter siswa melalui pembelajaran matematika caranya adalah melalui pembelajaran dikelas dengan mengajarkan pelajaran matematika kepada murid yang secara konsisten menanamkan kebiasaan-kebiasaan dan menanamkan prilaku yang berkarakter, dan juga memasukan nilai-nilai keislaman dalam pembelajaran matematika di kelas. Integrasi nilai-nilai keislaman yang dimaksud adalah memadukan nilai-nilai keislaman pada saat mengajarakan materi matematika tanpa menghilangkan 
unsur keunikan didalam matematika sehingga siswa nantinya tidak hanya cerdas dalam ilmu pengetahuan tetapi juga memiliki kecerdasan karakter yang religius.

\section{Nilai-nilai karakter dalam pembelajaran matematika}

Berdasarkan peraturan mentri Pendidikan Nasional nomor 22 tahun 2006 (dalam jurnal maxinus jaeng:2016), yang didalamnya berisi tentang tujuan matematika, maka didalamnya terdapat beberapa nilai pendidikan Karakter yang dapat dikembangkan melalui pembelajaran matematika yang didalamnya mencakup karakteristik pendidikan matematika diantaranya yaitu :

1. Disiplin

Karakter disiplin dapat terbentuk melalui pembelajaran matematika, karena di dalam pembelajaran matematika terdapat siswa dapat memahami aturan-aturan dan konsep-konsep yang telah disepakati. Nilai karakter yang diharapkan melalui pembelajaran matematika adalah siswa dapat menggunakan aturan dan konsep-konsep. Tujuannya siswa diharapkan selalu menaati aturan-aturan yang dibuat dan tidak melanggar sehingga menumbuhkan sikap disiplin.

2. Jujur

Matematika tidak menerima generalisasi yang berupa pengamatan, dalam ilmu matematika membutuhkan pembuktian untuk dapat menyatakan sesuatu itu dianggap benar, tidak bisa hanya dengan pengamatan saja tetapi harus di dapat dibuktikan. Implikasinya dapat menumbuhkan sifat jujur kepada siswa, sehingga kepribadian siswa yang terbentuk diharapkan selalu dapat dipercaya dalam perkataan, tindakan dan pekerjaanya karena selalu dapat menunjukan pembuktian dari setiap perkataan dan tindakannya.

3. Kerja Keras

Karakter yang ingin dibentuk adalah agar siswa tidak mudah putus asa. Dalam pembelajaran matematika siswa dilatih tekun, telaten dan juga teliti, hal ini dapat meningkatkan kerja keras siswa dalam mencapai sesuatu dan siswa tidak mudah putus asa.

4. Kreatif

Didalam pelajaran matematika seorang siswa belajar bagaimana cara menyelesaikan soal matematika, ada siswa yang bisa menyelesaikan dengan cara panjang dan ada juga yang bisa menyelesaikan dengan cara pendek tetapi benar. semakin siswa sering menyelesaikan soal matematika maka akan menumbuhkan siswa yang kreatif. Maka seseorang yang belajar matematika akan lebih kreatif untuk menyelesaikan persoalan.

5. Rasa ingin Tahu

Dalam pembelajaran matematika yang memunculkan rasa ingin tahu seeorang akan mengakibatkan seseorang terus ingin belajar sepanjang hidupnya. Terus menggali informasi-informasi yang berkaitan dengan lingkungannya. Matematika yang dipelajari memiliki banyak analogi sebagai pengetahuan rasional melatih peserta didik untuk mengetahui seuatu gejala alam yang mirip dengan pemikiran yang rasional.

6. Mandiri 
Dalam pelajaran matematika kita senantiasa menghadapi tantangan, berbagai permasalahan yang menuntut kita untuk menemukan solusi atau penyelesaiannya untuk itu peserta didik harus mampu memilki sikap yang tidak mudah bergantung pada orang lain namun, berupaya secara mandiri untuk menyelesaikan tugas-tugas yang dihadapi dengan baik.

7. Taggung Jawab

Kebiasaan yang disiplin dalam bernalar yang terbentuk dalam mempelajari matematika melahirkan suatu sikap tanggung jawab atau melaksanakan kewajiban yang seharusnya dilakukan baik tanggung jawab terhadap diri sendiri, masyarakat, negara dan Tuhan yang maha Esa.

Nilai-nilai karakter yang tekandung dalam pelajran matematika sangat banyak sekali. Hal ini harus diperhatikan oleh seorang guru matematika, Sebagai seorang guru dituntut untuk mampu menanamkan nilai-nilai karakter kepada siswanya. Kebanyakan guru saat ini hanya mampu mengajarkan materi mata pelajaran yang diampu saja tanpa memperhatikan integrasinya terhadap pendidikan karakter. Salah satu cara untuk menanamkan pendidikan karekater kepada siswa melalu pemebelajaran matematika yaitu guru harus menanamkan kebiasaan-kebiasaan dan menanamkan prilaku yang berkarakter, dan juga memasukan nilai-nilai keislaman dalam pembelajaran matematika di kelas.

Penanaman pendidikan karakter kepada siswa melalui pembelajaran matematika juga dapat dilakukan dengan memasukkan nilai-nilai keislaman di dalamnya, hal ini dikarenakan nilai-nilai Islam itu sangat menyokong pendidikan karakter siswa. Oleh karena itu dalam pembelajaran matematika guru diharapkan mampu mengintegrasikan nilai-nilai keislaman pada saat mengajar guna lebih menumbuhkan karakter siswa.

\section{Integrasi Nilai Keislaman dalam Matematika yang dapat membangun Karakter siswa}

Kata "Integrasi" berasal dari bahasa latin Integer, yang berarti utuh atau menyeluruh. Berdasarkan arti etimologi integrasi berarti membuat unsur-unsur tertentu menjadi satu kesatuan yang bukat dan utuh. Pembelajaran matematika Berbasis Pendidikan karakter merupakan proses pembelajaran yang melibatkan beragam unsur (bidang Studi, siswa, guru, dan lingkungan) sehingga tidak dapat disederhakan menjadi suatu konsep (sumarmo 2012). Menurut kementrian pendidikan nasional Nilai-nilai keislaman/religius adalah sikap dan prilaku yang patuh dalam melaksanakan ajaran agama yang dianutnya, toleran dalam pelaksanaan ibadah agama lain dan hidup rukun dengan pemeluk agama lain. Nilai-nilai Islam dapat diintegrasikan dalam pembelajaran matematika sehingga pembelajaran matematika tidak hanya mempu mengantarkan siswa pada ketercapaian pengetahuan umum saja tetapi juga ketercapaian pemahanan dan penerapan nilai-nilai keislaman.

Faiz Hamzah mengatakan bahwa integrasi Islam untuk pengetahuan matematiika dapat menggunakan pendekatan Inter-disipliner, yaitu dengan memasukan ayat-ayat kauniyah dalam Al-Qur'an kedalam materi pembelajaran 
untuk memperdalam dan memperkuat makna pemahaman yang dihasilkan. Integrasi nilai-nilai keislaman dalam matematika adalah berkaitan dengan usaha memadukan keilmuan matematika secara umum dengan islam tanpa harus menghilangkan keunikan-keunikan antara dua keilmuan tersebut.

Pembelajaran matematika yang berintegrasi keislaman disini berarti matematika yang diajarkan memadukan nilai-nilai keislaman didaalamnya, selalu mengaitkan antara ilmu matematika dengan ilmu islam. Ilmu matematika memiliki tiga kekutan dalam membentuk karakter yaitu:

1. kekuatan materi (konsep)

Konsep matematika sendiri sebenarnya sudah memiliki kekuatan untk membentuk moral.

2. kekutan metode pembelajaran

Melalui metode pembelajaran yang digunakan oleh guru juga dapat membentuk karakter siswa. Oleh karena itu guru harus memperhatikan pemilihan metode pembelajaran matematika, pilihlah metode yang mendukung pembelajaran siswa dan mendukung untuk pembentukan karakter siswa.

3. kekuatan karakter guru matematika

Karakter seorang guru juga berperan penting dalam pembentukan karakter siswa. Guru sebagai seorang yang digugu dan ditiru harus memiliki karakter yang baik sehingga nantinya siswa dapat meniru apa yang dicontohkan gurunya.

Ketika seorang guru mengajarakan ilmu matematika dengan memperhatikan ketiga hal tersebut, maka imu matematika menjadi suatu ilmu yang utuh dan bisa di pandang sebagai mata pelajaran yang mendidik karakter.

Penanaman karakter melalui konsep matematika yang berintegrasi keislaman Penanaman karakter religius/jiwa tauhid melalui konsep matematika, Bisa melaui pembelajaran matematika aljabar: Misalnya dalam materi Al-jabar seorang siswa diberi pertanyaan oleh gurunya yaitu : selesaikanlah bentuk Aljabar berikut $x+y-5 x=7 y$. Sebagai seorang guru dari soal tersebut harusnya menenkankan bahwa ada koefisien satu yang tidak di tulis tetapi nilainya ada. Disini bisa ditekankan kepada anak didik bahwa yang namanya sesuatu yang ada itu tidak harus kelihatan seperti Tuhan itu diyakini ada keberadaanya tetpi tidak kelihatan.

Dalam membentuk karakter siswa yang berinterasi keislaman maka harus pula diperhatikan kegiatan belajar mengajar guru di dalam kelas. Adapun kegiatan belajar mengajar guru didalam kelas menurut Muhammad Azhar:

1. Kegiatan Pendahuluan

Tahan ini merupaka tahap awal sebelum dimulainya kegiatan pembelajaran, kegiatannya seperti mengbsen siswa, menanyakan siswa yang hadir dll.

2. Kegiatan inti

Pada tahap ini guru sudah memulai menyampaikan materi pembelajaran.

3. Kegiatan evaluasi 
Dalam tahap ini guru memberikan postes baik lisan maupun tulisan dengan alat evaluasi yang disiapkan.

4. Kegiatan penutup

Di tahap ini guru menutup pembelajaran biasanya diakhir ada pemberian tugas dari guru.

Berdasakan langkah-langkah pembelajaran yang disebutkan oleh Muhammad Azhar, proses kegiatan belajar mengajar tersebut bisa diterapakan dalam kegiatan belajar mengajar dalam membagun karakter yang berintegrasi keislaman. Dalam proses pembelajaran guru seharusnya menyampaikan materi matematikan dengan di integrasikan terhadap nilai-nilai matematika. Tujuan agar siswa memiliki karakter yang baik sesuai dengan nilai-nilai keislaman. Jika ingin menumbuhkan kararkter siswa melalui pembelajaran matematika cara adalah dengan menanamkan kebiasaan kepada membagun karakter siswa melalui materi yang diajarkan dengan memasukan nilai-nilai keislaman.

\section{SIMPULAN}

Membagun pendidikan karakter siswa dapat dilakukan malalui pembelajaran matematika yang berintegrasi nilai-nilai keislaman. Nilai-nilai keislaman apabila ditanamkan kepada siswa itu akan berdampak baik dalam membentuk karakter siswa. Karena pada dasarnya nilai-nilai keislaman atau ilmu agama ilam sangat mendukung pembentukan karakter siswa. Pembentukan karakter siswa dilakukan oleh guru caranya adalah melalui pembelajaran dikelas dengan mengajarkan pelajaran matematika kepada murid yang secara konsisten menanamkan kebiasaan-kebiasaan dan menanamkan prilaku yang berkarakter, dan juga memasukan nilai-nilai keislaman dalam pembelajaran matematika di kelas.

\section{DAFTAR PUSTAKA}

Abdussaki. 2014. Matematika dalam Islam. Malang: Unit Penerbitan UIN Maulana Malik Ibrahim.

Agung Hartoyo.2015.Pembinaan Karakter Dalam Pembelajaran

Matematika. Jurnal Pendidikan Matematika. 1 (1), 8-21.

Annisah Kurniati. 2016. Pengembangan Modul Matematika Berbasis

Kontekstual Terintegrasi IImu Keislaman. 4 (1), 44-58.

Fadlun. 2017. Pengembangan Bahan Ajar Matematika Yang Terintegrasi

Nilai Keislaman Pada Materi Aritmatika Sosial di Kelas VII Sekolah

Menengah Pertama, Skripsi, 1-131.

Helian Dessi Kusumawati dan muhammad Aminudin. 2019. Menanamkan

Pendidikan Karakter Melalui Pembelajaran Matematika dengan

Mengembangkan Keterampilan Berfikir Kritis sebagai Salah Satu Upaya Meningkatkan Jiwa Nasionalisme Siswa SMA Negeri ! Ungkaran. Jurnal Penelitian Didaktik Matematika, 2 (2), 88-97.

Heris Hendriana. 2014. Membangun Kepercayaan Diri Siswa Melalui

Pembelajaran Matematika Humanis. Jurnal Pengajaran MIPA 19 
(1) $52-60$.

Linda Ayu Lovenidianan dan Endah Budi Rahaja. 2014. Kemampuan

Komunikasi Matematika Pada Penerapan Pembelajaran Aktif Team

Quis Materi Statistika. Jurnal IImiah Pendidikan Matemtika. 3 (3),

202-207.

Mahyudin Barni. 2019. Tantangan Pendidik Di Era Milenial. Jurnal

Transformatif. 3 (1). 111-116.

Maxinus Jaeng. 2016. Pendidikan Karakter Melalui Pendidikan

Matematika. Jurnal Pendidikan Matematika. 5 (3), 15-25.

Meri Andriani dan Zubaidah Amir. 2019. Membangun Self-Confidence

Siswa Melalui Pembelajaran Matematika. Desimal: Jurnal

Matematika. 2 (2), 147-153.

Muhammad Guntur, Arif Muchyidin, dan Widodo Winarso. 2017. Pengaruh

Penggunaan Bahan Ajar Matematika Bersuplemen Komik

Terhadap Kemandirian Belajar Siswa. Jurnal eduma. 6 (1), 43-51.

Nanang Supriadi. 2015. Membangun Kemampuan Koneksi Matematika

Melalui Buku Ajar Elektronik Interaktif (BEI) Yang Terintegrasi Nilai-

Nilai Keislaman.

Nurdyansyah. 2018. Peningkatan Moral Berbasis Islamic Math Crachter.

Skripsi.

Rahmi. 2013. Kontribus Matematika Dalam Pembentukan Karakter Siswa.

Jurnal Ekotrans.12 (1), 31-38. 